\title{
Transformability as a Wicked Problem: A Cautionary Tale?
}

\author{
Samia Sediri ${ }^{1,2,3, *} \mathbb{C}$, Michel Trommetter ${ }^{1}$, Nathalie Frascaria-Lacoste ${ }^{2}(\mathbb{D})$ and \\ Juan Fernandez-Manjarrés ${ }^{2}$ (D) \\ 1 Université Grenoble Alpes, INRAE, National Centre for Scientific Research CNRS, Grenoble INP, GAEL, \\ 38000 Grenoble, France; michel.trommetter@inrae.fr \\ 2 Université Paris-Saclay, National Centre for Scientific Research CNRS, AgroParisTech, Laboratory of Ecology \\ Systematics and Evolution ESE, 91405 Orsay, France; nathalie.frascaria@u-psud.fr (N.F.-L.); \\ juan.fernandez@u-psud.fr (J.F.-M.) \\ 3 Association ORÉE, 42 Rue du Faubourg Poissonnière, 75010 Paris, France \\ * Correspondence: samia.sediri@universite-paris-saclay.fr
}

Received: 15 June 2020; Accepted: 15 July 2020; Published: 22 July 2020

check for updates

\begin{abstract}
Transformability is increasingly promoted as a way of moving societies toward more sustainable futures in the era of the Anthropocene, mostly because the concept of resilience has fallen short in many instances where impacts on social-ecological systems are continuous, varied, and usually unknown. While such transformations can play a crucial role in improving the sustainability of social-ecological systems, they may lead to unexpected and undesirable outcomes. This literature review on social-ecological transformability and wicked problems seeks to shed light on and acknowledge some of the limitations of transformability regarding unforeseen conditions. We argue that wicked problems arise in transformation initiatives in the presence of high complexity, deep uncertainty, deep conflicts, and divergence among stakeholders, as well as scale mismatches concerning spatial, temporal, and institutional processes. Our findings may explain why some transformation initiatives fail to generate expected changes on the ground, mainly in two cases: (a) a polarized configuration that maintains the status quo of the system to be transformed and (b) an unforeseen transformation that causes the system to lurch from crisis to crisis. To conclude, we recommend using diagnostic questions to prevent wicked problems in social-ecological transformations.
\end{abstract}

Keywords: social-ecological system; resilience; transformability; sustainability; wicked problems; social complexity; uncertainty

\section{Introduction}

In this era of the Anthropocene [1,2], change in social-ecological systems [3], whether or not it is intended, seems unavoidable. The state of social-ecological systems (SESs) is continuously changing, but during the lifespan of an individual, there is a strong need to maintain these systems in ways that are sustainable and familiar to each generation $[4,5]$. Resilience, i.e., the capacity of a system to persist and reorganize in the face of change [6-9], has been a central concept in the literature of the last 20 years. In this line with thinking, resilience theory is criticized by scholars due to the lack of analytical power available to study the shifts and fundamental changes in the structure and functioning of SESs, or in other words, the transformations [10-12]. Considering the increase in uncertainties and the interconnectedness of crises, as can currently be observed through global climate change, transformations are necessary to prevent SESs from collapsing [13-15]. However, "having the capacity" to seize the opportunity of change in order to redirect a system toward sustainability pathways 
is challenging [4]. Indeed, when implementing actions on the ground, the achieved outcomes are sometimes very different to what is expected or desired. Anticipating the repercussions of change when managing SESs is not easy due to associated complexity and uncertainty (see Box 1). For example, in biodiversity conservation, policies and incentives are known to generate unintended pervasive impacts [16]. For instance, the creation of the Wolong Nature Reserve (southwestern China) to protect the giant panda has accelerated the degradation of the habitat instead of protecting it [17]. The authors reported that a natural forest conservation program was introduced in 2001 for local communities to monitor illegal forest harvesting. Unexpectedly, however, many households decided to split into smaller ones to collect more subsidies attributed to households as part of the program. The multiplication of households increased the demand for fuelwood and land for house construction [17,18]. In response, the local reserve management initiated three ecological restoration programs: the Grain for Green Program, the Natural Forest Protection Program, and the Switch from Fuelwood to Electricity Energy Program. A recent study [19] showed that these programs led to an increase of wildlife damage on the local people, probably because the Wolong Nature Reserve provided habitats for many wild species. This example illustrates the unexpected consequences of decisions and actions, which occur 20 years after the implementation of programs. The effects are difficult to predict, and the consequences go far beyond those initially intended.

Box 1. Complexity and uncertainty in social-ecological systems based on: Mollinga and m

SESs are seen as complex adaptive systems $[5,22,23]$. Complexity and uncertainty arise from several sources in SESs. Mollinga [20] has identified three types of complexity related to three sources of uncertainty discussed by Biggs et al., [21]:

Ontological complexity: SESs are characterized by the high heterogeneity of components with a diversity of interrelations. Uncertainty arises from interactions between the different components of the system, which also give rise to emergent properties that cannot be predicted from knowledge of the individual system parts.

Analytical complexity: Knowledge about the behavior of SESs is only partial, and not all the mechanisms operating in the systems and their interactions are known. SESs are dynamic; they continuously evolve and change. Here, uncertainty is related to the nonlinear dynamics of SESs. Thus, understanding these dynamics and interactions within an SES is a moving target.

Societal complexity: Systems are populated, managed, and governed by different groups of people for whom the system has different purposes, benefits, and meanings. Uncertainty arises from people's values and beliefs, interests, power, and risk tolerance, which play a role in making decisions about desired pathways.

Herein, we propose the wicked problem lens [24-26] to draw attention to particular features of intractable social and ecological issues, which may represent barriers to transformation initiatives such as indeterminacy in problem formulation, non-definitiveness in problem solutions, irreversible consequentiality, and individual uniqueness, among others. The concept of wicked problems was developed by Rittel and Webber [27] in their seminal article "Dilemmas in a general theory of planning." They aimed to describe emerging policy problems related to urban planning [27]. The wicked nature of these problems arises from their biophysical and social complexity and from divergent values related to multiple stakeholders' perceptions of them and their potential trade-offs with respect to the desirability of alternative outcomes [28,29].

As currently understood, transformability initiatives are candidates for creating wicked problems. Transformations are intrinsically pervaded by social complexity. They are the product of framing narratives and stakeholders' perceptions of problems, processes of change, and the desirability of the alternative trajectories of the system [30-33]. Social-ecological transformations involve a plethora of stakeholders with varying levels of power, whose values, interests, and goals are heterogeneous and often conflicting. Therefore, decisions about the pathway of change may suffer from myopia because of ambiguity and human limitations in information processing related to the formulation of both the problems and their solutions. For instance, "policy myopia" or "the inability to clearly see the horizon of the future policy environment in which impacts of the policy will develop" can lead to policy failure [34] (p. 2). 
The mechanisms at the root of social-ecological transformations are not clearly identified and understood [32,35]. Hence, creating new trajectories for a system with any level of consensus and reliability remains difficult because of the inherent complexity of the SESs and the uncertainties that they entail [36]. For instance, drivers and consequences of social actions may be intensified with retroaction and recursive loops, propelling the system outside of sustainable domains, even with cross-scale effects [37-40]. Surprises in SESs may also emerge without apparent warning [41,42].

Given these considerations, it is important to restrain from platonicity, i.e., our tendency to mistake the map for the territory [43], when dealing with social-ecological transformations. We believe that precaution is required instead of a shortsighted focus on the proximate drivers and consequences of change. This paper aims to examine the implications behind the transformability of SESs in the context of uncertainties and the emergence of wicked problems when facing the challenge of transformation. We structure our discussion in line with three specific questions. How do SES transformations become wicked? What are the factors upholding wickedness and their consequences for the transformation process? How can we prevent the creation of these wicked problems when devising transformations?

\section{What Is Wicked about a Problem?}

Wicked problems are defined as intractable issues found in many disciplines [44] that require the ability to forecast. The causes and effects of wicked problems are extremely difficult to identify and model, because most of the problems are interconnected to or are symptoms of other problems [45]. They are poorly formulated, boundary-spanning issues in which the nature of both the problems and the solutions may be strongly contested [46]. Rittel and Webber [27] defined 10 characteristics that define wicked problems (see Box 2).

Box 2. Characteristics of wicked problems after Rittel and Webber [27].

1. Wicked problems are difficult to define; there is no definitive formulation.

2. Wicked problems have no stopping rule.

3. Solutions to wicked problems are not true or false, but rather good or bad.

4. There is no immediate and ultimate test for solutions.

5. Every solution is a "one-shot operation"; there is no opportunity to learn by "trial-and-error", and attempts may have irreversible effects.

6. These problems do not have an enumerable set of possible and clear solutions.

7. Every wicked problem is essentially unique.

8. Every wicked problem may be a symptom of another problem.

9. The existence of a discrepancy representing a wicked problem can be explained in numerous ways.

10. The planner has "no right to be wrong", i.e., policymakers or planners are liable for the consequences of the solutions they generate, and the public have no tolerance or trust in initiatives that fail.

Wicked problems are socially and politically complex [47]. They are associated with social pluralism (the multiple interests and values of stakeholders), institutional complexity, and scientific uncertainty due to fragmentation and gaps in knowledge [48]. Institutional complexity is related to conflicting prescriptions from multiple institutional logics [49]. Institutional complexity is widely discussed in the governance of SESs due to coordination and/or collaboration problems that give rise to conflicts [50-53] where wickedness is frequently suspected. In fact, wicked problem analysis focuses on the role of stakeholder perceptions, values, and interests to explain how issues are scoped, priorities are set, and possible solutions are considered [54]. When groups of actors are facing debatable issues, their interpretations of the environment, their definition of the problems, and their development of strategies are all related to their perceptions based on their different life experiences [55].

Alford and Head [56] identified a spectrum of problem types (Figure 1), which provides some explanations about the features of wicked problems and also sheds light on the "features and intensities" of the different types of problems [48] (p. 6). 


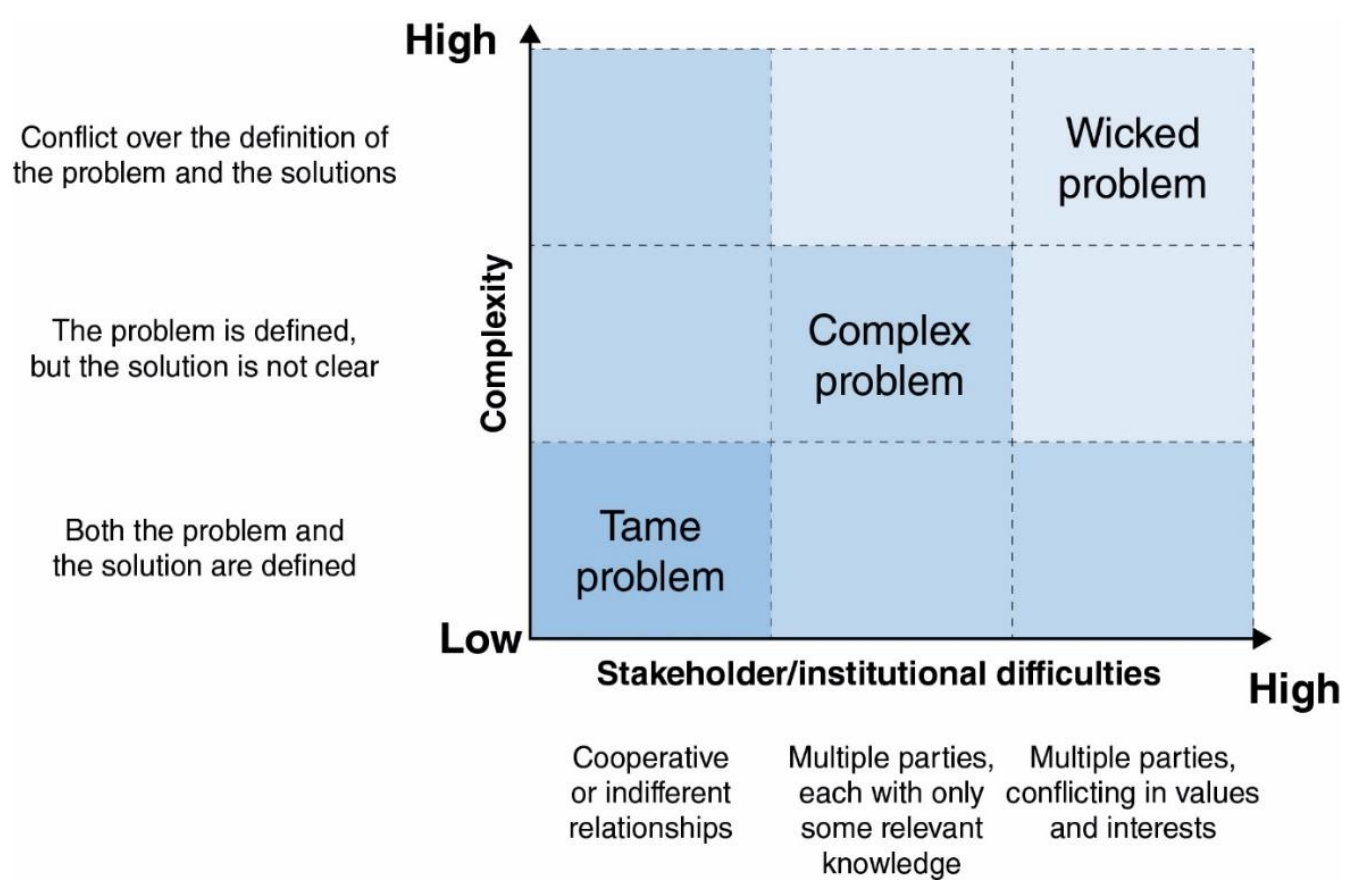

Figure 1. Spectrum of problem types formed by the two basic elements of wicked situations: The definition of the problem and the involved actors [56].

The three categories represent: (1) Tame problems, which are finite problems that do not change over time; they are addressed by science as definable elements with verifiable solutions, and there are no deep conflicts of interest among stakeholders. (2) Complex problems, which are defined by the ability to approach them from multiple perspectives with multiple possible solutions. (3) Wicked problems, which are generally "ill-defined" and resistant to a definitive solution. Between tame, complex, and wicked problems, there are also other problem types that vary in their degree of difficulty and complexity [56,57].

In a wicked problem, implementing any potential solution will change the nature of the problem, and as a result, the problem definition tends to change over time. Further, science-derived solutions are unable to definitively solve underlying and evolving problems, as they require a social and political approach [58]. Accordingly, wicked problems have been largely discussed in relation to normal science, i.e., the process of disciplinary puzzle-solving by experts [59], and post-normal science, i.e., the "approach to problem-solving strategies in which the role of science, still essential, is now appreciated in its full context of the uncertainties of natural systems and the relevance of human value" [60]. Batie [44] explored the differences between normal and post-normal science in the context of tame versus wicked problems. The author argues that the "assumptions and approaches" of normal science are unsuitable when addressing complexities and uncertainties related to wicked problems, which implies the need to deal actively with ignorance and uncertainty. According to [61], most problems have more than one plausible answer in practice, while many do not have a response. Moreover, solutions to one aspect of the problem may even reveal or create problems on another scale [27]. For instance, the purchase of land for biodiversity conservation can accelerate development pressure and displace threats to areas of higher conservation value [62], thus creating a wicked problem. Managers and policymakers therefore have to focus on a moving target. Indeed, working on wicked problems requires collaboration between the scientific community, experts, and society at large [63,64].

\section{Transformability: Between Theory and Practice}

Transformability relates to the social-ecological capacities that enable shifts from one regime to new pathways and even to the creation of new systems. Transformability has been defined as 
"the capacity to create a fundamentally new system when ecological, economic, or social structures make the existing system untenable" [9] (p. 1). It refers to the ability of the SES actors to cross thresholds and move systems into new paths of development [65-67]. Transformation means creating new "stability landscapes" [9] by introducing new components and ways to make a living [13]. Thus, transformation processes refer to fundamental changes in the structure, function, and relations within SESs, which lead to new patterns of interactions (e.g., among actors, institutions, and between societies and ecological systems) and outcomes [68-70].

Transformation is conceptualized as a necessary step once ecological, economic, and/or social conditions render the SES untenable [71]. In this view, transformation is not necessarily a choice but rather the last phase before or during the system collapse [72], for example, in the context of a natural disaster. The transformation of the SES can be in response to the identification of tipping points or thresholds $[67,73]$, or they could be driven by failures of past policies and actions, which make the system untenable or undesirable [35,74]. From this perspective, transformation is a deliberate initiative that intends to anticipate the redirection of the system onto a new path before structures make the existing system collapse [15].

SESs can sometimes be resilient but become trapped in undesirable situations such as the "poverty trap" [75,76], but the desirability of a system is human-centered. From an ecological perspective, Nelson et al. [67] argue that there is no presumption that one state is more desirable than another. Hence, social desires and goals serve as a point of comparison to evaluate the desirability of a given state, which can clearly raise controversies about the normative nature of such judgments of desirability as well as the responsibility of those who decide [15,32].

The untenable or undesirable situations of SESs and crises can be seen as opportunities for transformations, new ways of thinking, learning, and operating [13,50,77]. Indeed, a crisis can potentially be used productively to stimulate "safe-to-fail experimentation" [65,78], small-scale experiments, novelty, and learning within society $[79,80]$ and with nature. For instance, in a study about a climate-related disaster in Honduras, McSweeney and Coomes [81] demonstrated how after Hurricane Mitch, the rural Tawahka community became mobilized and initiated institutional change that served to enhance social-ecological resilience and improve livelihood contributions to the poor. The crisis induced by Hurricane Mitch therefore opened up a window of opportunity to improve the community's capacity to cope with storms and flooding and thereby enhanced their long-term resilience to extreme events [81]. Despite the lack of consensus about the types of changes that would actually happen, at least three phases are known to occur during transformations (Figure 2) $[74,77,82]$. The first phase is preparing the system for imminent change and the second is navigating the transition into a new direction. These two phases tend to be linked by the "window of opportunity" for change $[69,74,83]$. The third phase is about building the resilience of the new pathway. Phase 1 is often protracted until a window of opportunity allows progress to phases 2 and $3[77,80]$. 


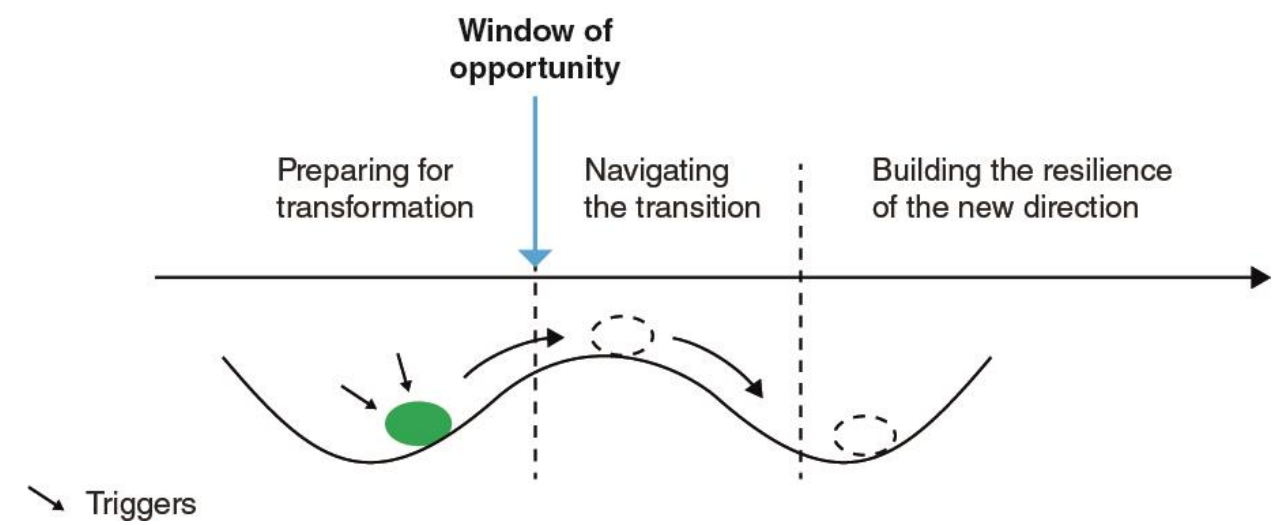

Figure 2. The three identified phases of social-ecological transformation processes (adapted from Olsson et al. [77] (pp. 263-285), in Adaptive Capacity and Environmental Governance, edited by Armitage D., Plummer R. (C) Springer-Verlag Berlin Heidelberg 2010, with permission from Springer Nature).

\section{Transformative but Wicked}

Some specific contexts of social complexity and uncertainty cause transformations to escalate from solving complex problems to creating wicked problems (Box 3). For example, non-recognition of the problem impedes the initiation of change and makes the situation wicked. Transformation processes involve multiple SES actors, and their ability to build a shared vision is crucial to transform a system. In institutional economics, it has been largely recognized that the initiation of collective action in natural resource management is mainly dependent on a common understanding of the problem and how it can be solved [84]. The choice of a desirable pathway will ultimately require consideration of the trade-offs among different priorities and for different stakeholders. Thus, disagreements may emerge among the constellation of actors whose interests are at stake. For instance, in water resource management, Olsson et al. [82] reported a case study of transformation in Mae Nam Ping Basin, Thailand, which failed to create a window for change because of the lack of a shared vision. The situation was characterized by divergence among stakeholders regarding the definition of the problem domain. As a result, there was no consensus about what the problem actually was, and the situation was locked in without effective change toward sustainable management.

Conflicts are also driven by the attitudes and power of the involved actors $[29,85]$. The ways in which one person influences the possibilities of another person [86] can explain how people's abilities (e.g., intimidating, influencing, and shaping desires) affect outcomes [87]. For example, the application of payments for ecosystem services (PESs), which aim to move a system toward sustainable pathways, produces unexpected negative effects due to the powerful non-legitimate agents attracted by the benefit of the rent [88]. Furthermore, cultural and emotional dimensions, traditions, and legacies could give rise to wicked problems when planning a social-ecological transformation (Box 3). Transformational change often involves, inter alia, shifts in perceptions, beliefs, values, and meanings that define the lifestyle of actors [89-91].

Considering that transformations occur in dynamic open systems, the capacity to seize the opportunity of change to implement transformative actions is likely to be influenced by a myriad of different factors. Here, we propose a range of factors, which, in our view, are at the origin of creating wicked problems when attempts are made to set up transformability projects (Box 4). We argue that the combination of (1) high complexity, (2) uncertainty, (3) deep conflicts, and (4) scale mismatches exacerbate wickedness in terms of social-ecological transformability. As discussed previously in Section 1, profound disagreements are coupled with social complexity and inherent uncertainty relating to the adaptive SES. This may create barriers to initiating transformations and thus drive undesirable long-term consequences. 
Box 3. Examples of wicked problems in transformations.

\begin{abstract}
Local scale
On an individual scale, the way in which the involved people will be affected is crucial in determining their willingness to support social-ecological transformation as a reorganization toward sustainability rather than a disturbance [92]. For example, Marshall et al. [93] investigated transformability among peanut farmers in Queensland, Australia. In response to the threat of drought due to climate change, the industry (farmers collectively) decided to transform its structure by translocating in the long term to a more agro-climatically amenable region for growing peanuts. The authors show how the social complexity of factors such as the influence of place and occupational attachments constrained the transformation. Peanut farmers with higher levels of attachment to their location or occupation were assessed (interviews) as having a lower capacity for change. Indeed, the strategy to relocate was subsequently abandoned [93]. These results were confirmed in another study on agriculture transformations under climate change [94].
\end{abstract}

Regional scale

Payments for ecosystem services (PESs) are seen as a positive incentive to trigger transformations toward sustainability. They are intended to simultaneously resolve environmental issues and reduce poverty [95]. However, scholars have shown that PESs produce counterintuitive negative socioeconomic consequences [96-98] such as the problems of rent seeking, power, payment volatility, and unequal bargaining [88,99-101], which lead to conflicts, eviction, and displacement in local communities. For instance, PESs increase the value of lands sustaining ecosystem services, but this in turn attracts new, powerful actors [102,103]. According to Kronenberg and Hubacek [101], "rent seeking emerges when new actors take over rents, often by manipulation, corruption or force, from those who would have been entitled to receive those rents in normal circumstances" [101] (p. 3). For instance, adverse effects are reported in the case of carbon sequestration projects, where profits from selling carbon credits did not reach the local communities but instead led to the appropriation of resources by the state and other powerful actors; see [104,105].

Global scale

Transformational change is challenged by the limited scope and knowledge of conditions allowing the emergence of large-scale institutions that can generate and sustain substantial changes on the ground [106,107]. One major example is the urgent need for global transformation to keep the earth system under the $1.5^{\circ} \mathrm{C}$ scenario. The decarbonization of energy systems is promoted as a solution but is still widely resisted by different actors $[108,109]$. Nevertheless, the international agreement on the reduction of greenhouse gas emissions, the "Kyoto Protocol", adopted in 1997 and entering into force in 2005, has not yet produced the desired cut-off effects as some nations claim their right to emit $\mathrm{CO}_{2}$ without restriction, thus creating tensions with those who try to abide by the protocol. Here, power (economic) and interest-driven processes are at stake, which leads to resistance and inertia, a wicked situation.

Socioeconomic drivers of change and their impacts on ecosystems operate on various spatial, administrative, and temporal scales [52,110-113], some of which lie beyond the authorities and jurisdictions tasked with the transformation. For instance, the mixed results of the global climate initiative "Reducing Emissions from Deforestation and Forest Degradation" (REDD+) may be explained by the lack of effective multi-level governance. Indeed, a dissonance between top-down policy approaches and local implementation was reported in Indonesia [114,115].

Box 4. Key factors upholding wickedness in transformability initiatives. (1) to (3) adapted from Head and Alford [48] and Head [116] and (4) contribution of the authors.

1. Complexity: The multiplicity of causes and dynamic interdependencies makes problems difficult to define and creates confusion regarding possible ramifications across the whole system.

2. Uncertainties: This relates to knowledge and the consequences of actions, particularly in the long term. The effects may be economically and/or ecologically irreversible.

3. Deep conflicts and divergence: These arise from the multiplicity of stakeholders with value conflicts and knowledge biases, which are all likely to exacerbate tensions in devising fundamental changes.

4. Scale mismatches (temporal, spatial, and administrative): These may generate contradictory objectives and shifting requirements that are difficult to diagnose. 


\section{Lost in Transformation}

Wicked problems could hamper the transformation processes. If transformation moves the SES toward desirable states in the long term, wicked problems may prevent it from doing so and produce unintended effects. By definition, wicked problems produce unanticipated consequences. Due to the complex dynamic of the systems (both the social and ecological domains), there are multiple explanations for the causes of change, and it therefore does not seem possible to identify an exhaustive inventory of all the possible challenges, opportunities, and alternative solutions associated with the transformation because these will continuously emerge as the issue is explored. Transformation in both processes and outcomes is messy and contested as it occurs on different scales and in different domains [117-119]. Wicked problems may impede transformations at different phases of the process. The determinant is the level of wickedness resulting from the combination of the factors listed above (Box 4). Here, we present two cases where wicked problems may arise and hamper transformation initiatives.

\subsection{Wicked Configurations}

Resistance to fundamental change is a critical component of transformation [4]. When stakeholders sustain marked oppositions and institutional misfit is significant or even implies contradictions, the situation becomes deeply conflictual. Powerful actors, who stand to lose much from changes toward sustainability, tend to be resistant to transformation and work to keep the dominant system in place to protect their interests. For example, $[120,121]$ studied low-carbon transitions in the UK, showing that the incumbent regime actors use different forms of power to "resist climate change-related pressures and to reposition themselves for low-carbon futures without fundamental system change"; see also [122]. Collaboration and the participation of new stakeholders may help to overcome these situations, working toward a "win-win" view of problem-solving and creating a window of opportunity. If, however, the deep conflict persists, both the problem and the stakeholders may be frozen in a wicked configuration (Figure 3a), a status quo, where phase 1 is often protracted until the conflict is resolved.

Wicked configurations emerge in social-ecological transformations when social complexity and institutional complexity increase the likelihood of conflict over the problem definition and its solutions. [92] explore this issue in terms of system identity, asserting that people's opinions about what they consider to be important guide their decisions and actions to respond to change; see also $[31,123]$.

In a critical review about transformation discourse, [124] speak of social differentiation or "how people are unevenly able and willing to take up opportunities of transformation" [124] (p. 9). Indeed, social-ecological change means different things to different people or groups because they understand systems and value them from the perspective of their own life experience, culture, knowledge, and emotions [125-127]. They may have contrasting needs, values, and even livelihood systems (see, e.g., [128]: Amazon rainforest). For instance, Olsson et al. [82] investigated how actions can succeed or fail to transform SESs into more desired configurations. They highlighted that disagreements and conflicting interests lead to "polarization among actor groups which hinders capacity building for ecosystem management" [82] (p. 6). Indeed, the absence of consensus about the definition of the problem and its related causes paves the way for the emergence of wicked problems, which in turn hamper the transformation path. [129] also draw attention to the impact of conflicts in transformation actions, arguing that transformations are more likely to materialize and endure if they are implemented before the onset of deep conflicts and before the actors become trapped in defensive positions. Moreover, transformative actions often involve contested trade-offs that disproportionately affect the population. For example, when perceptions of management costs and benefits differ between stakeholders, the likelihood of coordinating agreements and enforcement diminishes (e.g., greenhouse gas emissions reduction plans). One party is perceived to assert its actions at the expense of others. 


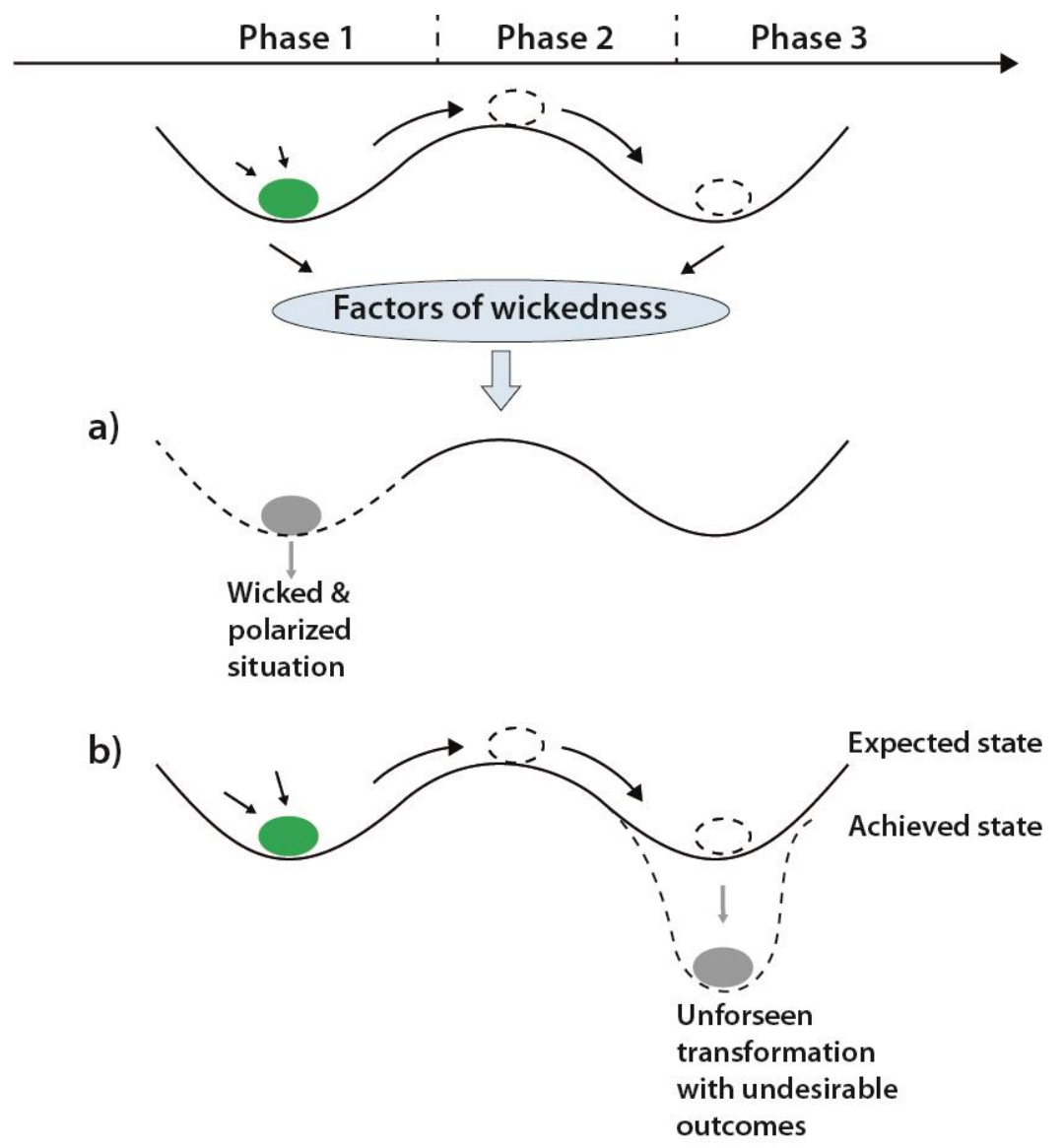

Figure 3. Social-ecological transformations and the emergence of wicked problems depicted in a ball-in-cup heuristic. Here, the green ball represents the current position of the SES, and the cup represents the trajectory of transformation. The grey ball represents (a) the status quo of the SES when conflicts and disagreements about the problem and the actions to undertake freeze the situation, even causing it to become polarized in phase 1 "preparing for transformation"; and (b) the shift to an unexpected and undesirable state due to factors such as deep uncertainty, high complexity, and scale mismatches. The factors presented here are hypothesized to play a key role in the creation of wicked problems in transformation initiatives.

This inescapable wickedness gives rise to two risks qualified as traps by DeFries and Nagendra [130]: (i) the risk of oversimplifying the wicked problem and assuming that a technical solution will fix it, and (ii) the risk of making the problem overly complex and driving inertia or the trap of inaction. Another type of trap arises from the risk of developing competitive strategies that assume a zero-sum game to solve the wicked problem, i.e., a situation in which an advantage that is won by one of two sides is lost by the other. This drives self-interested collaboration, and win-lose strategies permeate all interactions among stakeholders [131,132]. From this perspective, [133] pointed out that competition and conflict over natural resources are not always caused by resource scarcity per se but can be caused by the "greed of power-holders" or the failure of government regimes [133,134].

\subsection{Unforeseen Transformations}

Complex issues are likely to generate knowledge gaps, diverse interests, and a wide range of stakeholder perspectives, all of which create higher levels of uncertainty and ambiguity. The non-recognition of wicked problems when attempting to move or transform a system to a new pathway with more sustainability can give rise to another problem. Wicked problems generally lack clear solutions because each problem is linked to other problems, and the nature and characterization of each one cannot be isolated [27]. Hence, transformation may lurch from crisis to crisis (Figure 3b). 
Consequences are unintentional and unforeseen by decision-makers: "the more complex the system, the less likely are intentions of transformations to succeed" [135] (p. 65). SES trajectories are influenced by many factors ranging from a local to a global scale, including climate change, economies, and government policies [37]. As a result, decision-making is very difficult. For example, global-scale processes shape human decisions and market at a local level, which can retroactively affect individuals and ecosystems elsewhere [37,38,41].

In the context of climate change, the need to transform energy systems away from dependence on fossil fuels creates incentives to promote the use of renewable energy sources. In major renewable energy markets, bioenergy from biomass is the most important renewable energy source. Yet a systemic shift to biofuels may slow climate change but lead to destructive land-use changes and biodiversity loss around the world [136]. Additionally, biofuel production creates other problems by negatively affecting the availability of freshwater for biodiversity and wetland species; see, e.g., [137].

\section{Preventing Wickedness in Transformations}

With our analysis, we seek to raise awareness about the emergence of wicked problems when devising social-ecological transformations. Well-prepared transformations require a thorough consideration of what needs to be changed, how to implement change, and with whom. Here, we argue that transformations necessitate the adoption of an analysis that is consistent with, rather than ignores, the key features of wicked problems in transformation initiatives (Box 3). Dealing with wicked problems requires us to increase the attention accorded to factors that shape wickedness, such as stakeholder conflicts, complexity, uncertainty, and scales. Hence, understanding how the identified wickedness factors constrain the implementation of transformation is an essential step to achieving successful outcomes. Rittel and Weber's ten propositions tend to characterize a wicked problem, but they do not provide a test for determining whether a problem is wicked in the first place [138]. Further, the existence of disagreements among stakeholders does not automatically make a problem wicked, and not all failed transformations are wicked. Therefore, to categorize an issue as a wicked problem, it is fundamental to explore its levels of complexity and uncertainty as well as the extent of value-based divergence among stakeholders [54,116]. Ultimately, it is necessary develop an approach that provides insights into the possible emergence of wicked problems and the implications of social-ecological transformations. Based on diagnostic approaches $[139,140]$, herein we outline a list of diagnostic questions that could be applied when planning for social-ecological transformations (Figure 4). We consider deep stakeholder conflicts, complexity, uncertainty, and scale mismatches to be the preconditions of wicked problems, which, when present, imply that the issue will be intractable and must be dealt with using specific approaches; see [24,25,141-145]. "Diagnostic approaches aim to understand the identity of a system and the context in which it functions" [146] (p. 1174).

The long-term goal of SES sustainability is to recognize which combination of factors tends to lead to a relatively sustainable pathway and which combination tends to result in resource and system collapse [147]. Thus, when using these questions, the objective is to gather information about these factors in order to anticipate or adapt the responses to change. These diagnosis questions could help to identify factors or variables underlying the emergence of wicked problems when devising social-ecological transformations.

This procedure particularly helps define the problem domain, identify the involved actors, and initiate concerted agenda-setting. Here, we emphasize the work of stakeholders in improving coordination, collaboration, and trust, as well as managing divergences and conflicts. This also helps provide insights about people's willingness to accept long-term trade-offs and expected outcomes.

The problem situation may stretch across scales and levels of the planned transformation. Consequently, the multifunctionality of ecosystems and their multilevel governance must be considered in space and time in order to avoid overlapping and contradictory objectives. Considering the unpredictability of the SES, it seems important to prevent it from inducing undesirable, even irreversible, 
effects when initiating change and to prepare it for the unexpected by developing alternatives given that problems continue to evolve [148].

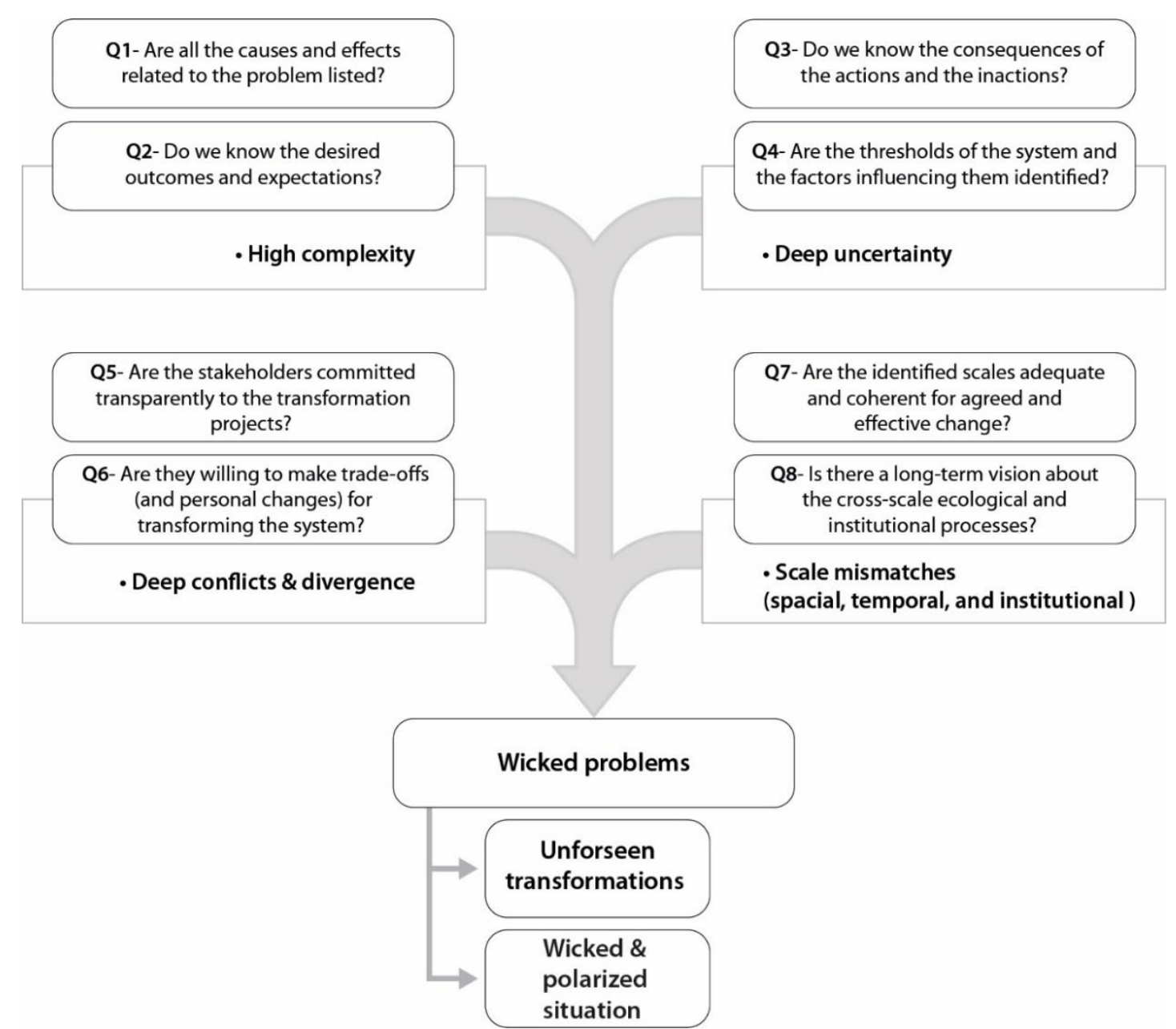

Figure 4. Diagnostic questions to prevent the emergence of wicked problems in social-ecological transformations. If one or more of the check-list questions remain unanswered (or the answer is no), then the probability of wicked problems existing in the transformation initiative is high.

Further, many of the diagnostic questions (Figure 4) directly address issues of governance. Once the context of wickedness is determined, different governance approaches may be mobilized to tackle wicked problems; see, e.g., [26,46,55,149-152]. We believe understanding the elements of wickedness is a prerequisite for governing and managing wicked issues, which in turn, according to [26,153], renews governance theories. As noticed by [153], this wickedness calls for "street-level observations of governance practices" to analyze how people in their daily practices deal with wickedness. From this perspective, [154,155] highlight the necessity to focus on "individual and organizational capacities" that can bring key elements to understanding and improving SES trajectories; see also [142,156,157]. Whether our current knowledge about the governance of wicked issues may also be applied to pre-transformation situations is a central conceptual difficulty to be explored in future research because social-ecological transformation entails new governance structures and goals.

\section{Concluding Remarks}

The challenges highlighted here simply indicate that transformability is more difficult than is generally acknowledged because of the many social and ecological factors involved. In this article, we argue that the transformation of SESs may be framed as wicked under specific conditions. 
The objective has been to gain insight into critical factors that prevent the SES from moving toward a new desirable pathway while avoiding undesired transformation paths. These factors include (1) high complexity, (2) deep uncertainty, (3) deep conflicts and divergence among stakeholders, and (4) scale mismatches. We argue that these are the cause of wicked problems when preparing a system for change and creating a new sustainable path of development. The review presented here emphasizes the role of wickedness in creating new unexpected situations: (Figure 3a) wicked or polarized configuration and (Figure 3b) unforeseen transformation. These findings might explain why some windows of opportunity fail to generate expected changes on the ground. Consequently, analyzing transformation processes from a wicked perspective may help generate a valuable understanding of the strategies that should be developed when navigating the preparation of change and being aware of the factors of wickedness before focusing on opportunities for transformational change. A solid understanding of the attributes that confer wickedness to a situation (problem) can better inform the transformation processes and provide the empirical basis to catalyze change. From this perspective, we developed a list of diagnostic questions as a basis from which to understand how the creation of wicked problems in social-ecological transformation can be limited by identifying critical barriers within the processes. Additionally, testing these diagnostic questions will help generate insights that are potentially helpful in addressing the challenges of transformations and even refine the questions, especially the aspects related to the human capacity and ingenuity to deal with wicked situations. Thus, understanding and addressing the governance and political challenges of social-ecological transformability is where further research might make a difference in terms of operationalizing opportunities for changes.

Future research is also needs to analyze different case studies of transformations that failed to reach the expected social and ecological objectives and identify the factors shaping wickedness in the process.

Author Contributions: S.S. conceived, designed, and wrote the paper; J.F.-M., suggested the inclusion of transformability aspects after editing an earlier version of the manuscript. M.T., N.F.-L., J.F.-M., edited the manuscript. All authors have read and agreed to the published version of the manuscript.

Funding: This research was funded by the framework of PhD grant "Cifre" from the association Orée, Lifti, Eifer, Suez, subsidized by the ANRT (convention number 2017/1090).

Acknowledgments: We are extremely grateful for the anonymous reviewers for their insightful comments and suggestions.

Conflicts of Interest: The authors declare no conflict of interest. The funders had no role in the writing of the manuscript.

\section{References}

1. Crutzen, P.J. Geology of mankind. Nature 2002, 415, 23. [CrossRef]

2. Steffen, W.; Crutzen, J.; McNeill, J.R. The Anthropocene: Are humans now overwhelming the great forces of Nature? Ambio 2007, 36, 614-621. [CrossRef]

3. Berkes, F.; Folke, C.; Colding, J. Linking Social and Ecological Systems: Management Practices and Social Mechanisms for Building Resilience; Cambridge University Press: Cambridge, UK, 1998; ISBN 978-0-521-78562-4.

4. Herrfahrdt-Pahle, E.; Pahl-Wostl, C. Continuity and Change in Social-ecological Systems: The Role of Institutional Resilience. Ecol. and Soc. 2012, 17, 8. [CrossRef]

5. Levin, S.; Xepapadeas, T.; Crepin, A.S.; Norberg, J.; De Zeeuw, A.; Folke, C.; Hughes, T.; Arrow, K.; Barrett, S.; Daily, G.; et al. Social-ecological systems as complex adaptive systems: Modeling and policy implications. Environ. Dev. Econ. 2013, 18, 111-132. [CrossRef]

6. Folke, C.; Carpenter, S.; Elmqvist, T.; Gunderson, L.; Holling, C.S.; Walker, B. Resilience and sustainable development: Building adaptive capacity in a world of transformations. Ambio 2002, 31, 437-440. [CrossRef] [PubMed]

7. Folke, C. Resilience: The emergence of a perspective for social-ecological systems analyses. Glob. Environ. Chang.-Hum. Policy Dimens. 2006, 16, 253-267. [CrossRef]

8. Gunderson, L.; Folke, C. Resilience-Now more than ever. Ecol. Soc. 2005, 10, 22-27. [CrossRef] 
9. Walker, B.; Hollin, C.S.; Carpenter, S.R.; Kinzig, A. Resilience, adaptability and transformability in social-ecological systems. Ecol. Soc. 2004, 9, 5-14. [CrossRef]

10. Gelcich, S.; Hughes, T.P.; Olsson, P.; Folke, C.; Defeo, O.; Fernández, M.; Foale, S.; Gunderson, L.H.; Rodríguez-Sickert, C.; Scheffer, M.; et al. Navigating transformations in governance of Chilean marine coastal resources. Proc. Natl. Acad. Sci. USA 2010, 107, 16794. [CrossRef] [PubMed]

11. Pelling, M.; Manuel-Navarrete, D. From Resilience to Transformation: The Adaptive Cycle in Two Mexican Urban Centers. Ecol. Soc. 2011, 16, 11-22. [CrossRef]

12. Jerneck, A.; Olsson, L. Adaptation and the poor: Development, resilience and transition. Clim. Policy 2008, 8, 170-182. [CrossRef]

13. Folke, C.; Carpenter, S.R.; Walker, B.; Scheffer, M.; Chapin, T.; Rockstrom, J. Resilience Thinking: Integrating Resilience, Adaptability and Transformability. Ecol. Soc. 2010, 15, 20-29. [CrossRef]

14. Westley, F.; Olsson, P.; Folke, C.; Homer-Dixon, T.; Vredenburg, H.; Loorbach, D.; Thompson, J.; Nilsson, M.; Lambin, E.; Sendzimir, J.; et al. Tipping Toward Sustainability: Emerging Pathways of Transformation. Ambio 2011, 40, 762-780. [CrossRef] [PubMed]

15. O'Brien, K. Global environmental change II: From adaptation to deliberate transformation. Prog. Hum. Geogr. 2012, 36, 667-676. [CrossRef]

16. Steffen, W. Australia's Biodiversity and Climate Change; CSIRO Publishing: Collingwood, Australia, 2009; ISBN 0-643-10182-9.

17. Liu, J.G.; Linderman, M.; Ouyang, Z.Y.; An, L.; Yang, J.; Zhang, H.M. Ecological degradation in protected areas: The case of Wolong Nature Reserve for giant pandas. Science 2001, 292, 98-101. [CrossRef]

18. Liu, J.; Hull, V.; Carter, N.; Viña, A.; Yang, W. Framing sustainability of coupled human and natural systems. In Pandas and People: Coupling Human and Natural Systems for Sustainability; Oxford University Press: Oxford, UK, 2016.

19. Xu, J.Y.; Wei, J.Y.; Liu, W.H. Escalating human-wildlife conflict in the Wolong Nature Reserve, China: A dynamic and paradoxical process. Ecol. Evol. 2019, 9, 7273-7283. [CrossRef]

20. Mollinga, P.P. Boundary Work and the Complexity of Natural Resources Management. Crop. Sci. 2010, 50, S1-S9. [CrossRef]

21. Biggs, R.; Rhode, C.; Archibald, S.; Kunene, L.M.; Mutanga, S.S.; Nkuna, N.; Ocholla, P.O.; Phadima, L.J. Strategies for managing complex social-ecological systems in the face of uncertainty: Examples from South Africa and beyond. Ecol. Soc. 2015, 20, 52. [CrossRef]

22. Levin, S.A. Ecosystems and the Biosphere as Complex Adaptive Systems. Ecosystems 1998, 1, $431-436$. [CrossRef]

23. Holling, C.S. Understanding the Complexity of Economic, Ecological, and Social Systems. Ecosystems 2001, 4, 390-405. [CrossRef]

24. Xiang, W.N. Working with wicked problems in socio-ecological systems: Awareness, acceptance, and adaptation. Landsc. Urban Plan. 2013, 110,1-4. [CrossRef]

25. Head, B.W.; Xiang, W.N. Working with wicked problems in socio-ecological systems: More awareness, greater acceptance, and better adaptation. Landsc. Urban Plan. 2016, 154, 1-3. [CrossRef]

26. Termeer, C.; Dewulf, A.; Biesbroek, R. A critical assessment of the wicked problem concept: Relevance and usefulness for policy science and practice. Policy Soc. 2019, 38, 167-179. [CrossRef]

27. Rittel, H.W.J.; Webber, M.M. Dilemmas in a general theory of planning. Policy Sci. 1973, 4, 155-169. [CrossRef]

28. Davies, K.K.; Fisher, K.T.; Dickson, M.E.; Thrush, S.F.; Le Heron, R. Improving ecosystem service frameworks to address wicked problems. Ecol. Soc. 2015, 20, 37. [CrossRef]

29. Mason, T.H.E.; Pollard, C.R.J.; Chimalakonda, D.; Guerrero, A.M.; Kerr-Smith, C.; Milheiras, S.A.G.; Roberts, M.; Ngafack, P.R.; Bunnefeld, N. Wicked conflict: Using wicked problem thinking for holistic management of conservation conflict. Conserv. Lett. 2018, 11, e12460. [CrossRef]

30. Pelling, M. Adaptation to Climate Change: From Resilience to Transformation; Routledge: London, UK, 2010; ISBN 1-134-02201-8.

31. O'Brien, K.L.; Wolf, J. A values-based approach to vulnerability and adaptation to climate change. WIREs Clim. Chang. 2010, 1, 232-242. [CrossRef]

32. Moore, M.-L.; Tjornbo, O.; Enfors, E.; Knapp, C.; Hodbod, J.; Baggio, J.A.; Norström, A.; Olsson, P.; Biggs, D. Studying the complexity of change: Toward an analytical framework for understanding deliberate social-ecological transformations. Ecol. Soc. 2014, 19, 54. [CrossRef] 
33. Görg, C.; Brand, U.; Haberl, H.; Hummel, D.; Jahn, T.; Liehr, S. Challenges for social-ecological transformations: Contributions from social and political ecology. Sustainability 2017, 9, 1045. [CrossRef]

34. Nair, S.; Howlett, M. Policy myopia as a source of policy failure: Adaptation and policy learning under deep uncertainty. Policy Polit. 2017, 45, 103-118. [CrossRef]

35. Walker, B.; Gunderson, L.; Kinzig, A.; Folke, C.; Carpenter, S.; Schultz, L. A handful of heuristics and some propositions for understanding resilience in social-ecological systems. Ecol. Soc. 2006, 11, 13-28. [CrossRef]

36. Bai, X.; van der Leeuw, S.; O’Brien, K.; Berkhout, F.; Biermann, F.; Brondizio, E.S.; Cudennec, C.; Dearing, J.; Duraiappah, A.; Glaser, M.; et al. Plausible and desirable futures in the Anthropocene: A new research agenda. Glob. Environ. Chang. 2016, 39, 351-362. [CrossRef]

37. Berkes, F.; Hughes, T.P.; Steneck, R.S.; Wilson, J.A.; Bellwood, D.R.; Crona, B.; Folke, C.; Gunderson, L.H.; Leslie, H.M.; Norberg, J.; et al. Ecology - Globalization, roving bandits, and marine resources. Science 2006, 311, 1557-1558. [CrossRef] [PubMed]

38. Liu, J.G.; Dietz, T.; Carpenter, S.R.; Alberti, M.; Folke, C.; Moran, E.; Pell, A.N.; Deadman, P.; Kratz, T.; Lubchenco, J.; et al. Complexity of coupled human and natural systems. Science 2007, 317, 1513-1516. [CrossRef]

39. Liu, J.; V, H.; Yang, W.; Vina, A.; X, C.; Ouyang, Z.; Zhang, H. Across Local to Global Coupled Human and Natural Systems. In Pandas and People: Coupling Human and Natural Systems for Sustainability; Oxford University Press: Oxford, UK, 2016; pp. 187-188.

40. Folke, C.; Jansson, A.; Rockstrom, J.; Olsson, P.; Carpenter, S.R.; Chapin, F.S.; Crepin, A.S.; Daily, G.; Danell, K.; Ebbesson, J.; et al. Reconnecting to the Biosphere. Ambio 2011, 40, 719-738. [CrossRef]

41. Preiser, R.; Biggs, R.; De Vos, A.; Folke, C. Social-ecological systems as complex adaptive systems: Organizing principles for advancing research methods and approaches. Ecol. Soc. 2018, 23, 46. [CrossRef]

42. Pace, M.L.; Carpenter, S.R.; Cole, J.J. With and without warning: Managing ecosystems in a changing world. Front. Ecol. Environ. 2015, 13, 460-467. [CrossRef]

43. Taleb, N.N. The Black Swan: The Impact of the Highly Improbable; Random House Publishing Group, Inc.: New York, NY, USA, 2007; Volume 2, ISBN 1-58836-583-2.

44. Batie, S.S. Wicked Problems and Applied Economics. Am. J. Agric. Econ. 2008, 90, 1176-1191. [CrossRef]

45. Game, E.T.; Meijaard, E.; Sheil, D.; McDonald-Madden, E. Conservation in a Wicked Complex World; Challenges and Solutions. Conserv. Lett. 2014, 7, 271-277. [CrossRef]

46. Weber, E.P.; Khademian, A.M. Wicked Problems, Knowledge Challenges, and Collaborative Capacity Builders in Network Settings. Public Adm. Rev. 2008, 68, 334-349. [CrossRef]

47. Peters, B.G. What is so wicked about wicked problems? A conceptual analysis and a research program. Policy Soc. 2017, 36, 385-396. [CrossRef]

48. Head, B.W.; Alford, J. Wicked Problems: Implications for Public Policy and Management. Adm. Soc. 2015, 47, 711-739. [CrossRef]

49. Greenwood, R.; Raynard, M.; Kodeih, F.; Micelotta, E.R.; Lounsbury, M. Institutional Complexity and Organizational Responses. Acad. Manag. Ann. 2011, 5, 317-371. [CrossRef]

50. Folke, C.; Hahn, T.; Olsson, P.; Norberg, J. Adaptive governance of social-ecological systems. Annu. Rev. Environ. Resour. 2005, 30, 441-473. [CrossRef]

51. Folke, C. Social-ecological systems and adaptive governance of the commons. Ecol. Res. 2007, 22, 14-15. [CrossRef]

52. Folke, C.; Pritchard, L.; Berkes, F.; Colding, J.; Svedin, U. The problem of fit between ecosystems and institutions: Ten years later. Ecol. Soc. 2007, 12, 30-68. [CrossRef]

53. Lubell, M.; Robins, G.; Wang, P. Network structure and institutional complexity in an ecology of water management games. Ecol. Soc. 2014, 19, 23. [CrossRef]

54. Head, B.W. Forty years of wicked problems literature: Forging closer links to policy studies. Policy Soc. 2019, 38, 180-197. [CrossRef]

55. van Bueren, E.M.; Klijn, E.H.; Koppenjan, J.F.M. Dealing with wicked problems in networks: Analyzing an environmental debate from a network perspective. J. Public Adm. Res. Theory 2003, 13, 193-212. [CrossRef]

56. Alford, J.; Head, B.W. Wicked and less wicked problems: A typology and a contingency framework. Policy Soc. 2017, 36, 397-413. [CrossRef]

57. Andersson, C.; Törnberg, P. Wickedness and the anatomy of complexity. Futures 2018, 95, 118-138. [CrossRef] 
58. Kreuter, M.W.; Rosa, C.D.; Howze, E.H.; Baldwin, G.T. Understanding Wicked Problems: A Key to Advancing Environmental Health Promotion. Health Educ. Behav. 2004, 31, 441-454. [CrossRef] [PubMed]

59. Kuhn, T.S. Criticism and the growth of knowledge: Proceedings of the International Colloquium in the Philosophy of Science, London, 1965; Cambridge University Press: Cambridge, UK, 1970; Volume 4, ISBN 0-521-09623-5.

60. Funtowicz, S.; Ravetz, J. Post-normal science. Science and Governance under conditions of complexity. In Interdisciplinarity in Technology Assessment; Springer: Berlin, Germany, 2001; pp. 15-24.

61. Ravetz, I.R. What is post-normal science. Futures-J. Forecast. Plan. Policy 1999, 31, 647-654.

62. Armsworth, P.R.; Daily, G.C.; Kareiva, P.; Sanchirico, J.N. Land market feedbacks can undermine biodiversity conservation. Proc. Natl. Acad. Sci. USA 2006, 103, 5403-5408. [CrossRef] [PubMed]

63. Mauser, W.; Klepper, G.; Rice, M.; Schmalzbauer, B.S.; Hackmann, H.; Leemans, R.; Moore, H. Transdisciplinary global change research: The co-creation of knowledge for sustainability. Curr. Opin. Environ. Sustain. 2013, 5, 420-431. [CrossRef]

64. Brandt, P.; Ernst, A.; Gralla, F.; Luederitz, C.; Lang, D.J.; Newig, J.; Reinert, F.; Abson, D.J.; Wehrden, H. A review of transdisciplinary research in sustainability science. Ecol. Econ. 2013, 92, 1-15. [CrossRef]

65. Folke, C.; Biggs, R.; Norstrom, A.V.; Reyers, B.; Rockstrom, J. Social-ecological resilience and biosphere-based sustainability science. Ecol. Soc. 2016, 21, 41. [CrossRef]

66. Walker, B. A resilience approach to integrated assessment. Integr. Assess. 2005, 5, 77-97.

67. Nelson, D.R.; Adger, W.N.; Brown, K. Adaptation to Environmental Change: Contributions of a Resilience Framework. Annu. Rev. Environ. Resour. 2007, 32, 395-419. [CrossRef]

68. Cumming, G.S.; Collier, J. Change and identity in complex systems. Ecol. Soc. 2005, 10, 29-42. [CrossRef]

69. Chapin, F.S.; Carpenter, S.R.; Kofinas, G.P.; Folke, C.; Abel, N.; Clark, W.C.; Olsson, P.; Smith, D.M.S.; Walker, B.; Young, O.R.; et al. Ecosystem stewardship: Sustainability strategies for a rapidly changing planet. Trends Ecol. Evol. 2010, 25, 241-249. [CrossRef] [PubMed]

70. Feola, G. Societal transformation in response to global environmental change: A review of emerging concepts. Ambio 2015, 44, 376-390. [CrossRef] [PubMed]

71. Walker, B.; Salt, D. Resilience Thinking: Sustaining Ecosystems and People in a Changing World; Island Press: Washington, DC, USA, 2012; ISBN 1-59726-622-1.

72. Nalau, J.; Handmer, J. When is transformation a viable policy alternative? Environ. Sci. Policy 2015, 54, 349-356. [CrossRef]

73. Scheffer, M.; Carpenter, S.; Foley, J.A.; Folke, C.; Walker, B. Catastrophic shifts in ecosystems. Nature 2001, 413, 591-596. [CrossRef] [PubMed]

74. Olsson, P.; Folke, C.; Hahn, T. Social-ecological transformation for ecosystem management: The development of adaptive co-management of a wetland landscape in southern Sweden. Ecol. Soc. 2004, 9, 2-28. [CrossRef]

75. Carpenter, S.R.; Brock, W.A. Adaptive Capacity and Traps. Ecol. Soc. 2008, 13, 3-29. [CrossRef]

76. Enfors, E. Social-ecological traps and transformations in dryland agro-ecosystems: Using water system innovations to change the trajectory of development. Glob. Environ. Chang. Hum. Policy Dimens. 2013, 23, 51-60. [CrossRef]

77. Olsson, P.; Bodin, Ö.; Folke, C. Building Transformative Capacity for Ecosystem Stewardship in Social-Ecological Systems. In Adaptive Capacity and Environmental Governance; Armitage, D., Plummer, R., Eds.; Springer: Berlin/Heidelberg, Germany, 2010; pp. 263-285. ISBN 978-3-642-12194-4.

78. Rockström, J.; Steffen, W.; Noone, K.; Persson, Å.; Chapin, F.S.; Lambin, E.F.; Lenton, T.M.; Scheffer, M.; Folke, C.; Schellnhuber, H.J.; et al. A safe operating space for humanity. Nature 2009, 461, 472-475. [CrossRef]

79. Gunderson, L.H.; Holling, C.S. Panarchy: Understanding Transformations in Human and Natural Systems; Island Press: Washington, DC, USA, 2002; ISBN 1559638575.

80. Folke, C.; Chapin, F.S.; Olsson, P. Transformations in Ecosystem Stewardship. In Principles of Ecosystem Stewardship: Resilience-Based Natural Resource Management in a Changing World; Folke, C., Kofinas, G.P., Chapin, F.S., Eds.; Springer: New York, NY, USA, 2009; pp. 103-125. ISBN 978-0-387-73033-2.

81. McSweeney, K.; Coomes, O.T. Climate-related disaster opens a window of opportunity for rural poor in northeastern Honduras. Proc. Natl. Acad. Sci. USA 2011, 108, 5203-5208. [CrossRef]

82. Olsson, P.; Gunderson, L.H.; Carpenter, S.R.; Ryan, P.; Lebel, L.; Folke, C.; Holling, C.S. Shooting the rapids: Navigating transitions to adaptive governance of social-ecological systems. Ecol. Soc. 2006, 11, 18-39. [CrossRef] 
83. Rockström, J.; Falkenmark, M.; Folke, C.; Lannerstad, M.; Barron, J.; Enfors, E.; Gordon, L.; Heinke, J.; Hoff, H.; Pahl-Wostl, C. Water Resilience for Human Prosperity; Cambridge University Press: Cambridge, UK, 2014; ISBN 1-139-86760-1.

84. Ostrom, E. Understanding Institutional Diversity; Princeton University Press: Princeton, NJ, USA, 2005; ISBN 978-0-691-12238-0.

85. Raik, D.B.; Wilson, A.L.; Decker, D.J. Power in Natural Resources Management: An Application of Theory. Soc. Natur. Res. 2008, 21, 729-739. [CrossRef]

86. Uphoff, N. Distinguishing Power, Authority \& Legitimacy: Taking Max Weber at His Word by Using Resources-Exchange Analysis. Polity 1989, 22, 295-322. [CrossRef]

87. Boonstra, W.J. Conceptualizing power to study social-ecological interactions. Ecol. Soc. 2016, $21,21$. [CrossRef]

88. Kronenberg, J.; Hubacek, K. From poverty trap to ecosystem service curse. Sustain. Sci. 2016, 11, 903-907. [CrossRef]

89. Westley, F.; Antadze, N. Making a difference: Strategies for scaling social innovation for greater impact. Innov. J. 2010, 15, 1-19.

90. Pelling, M.; O’Brien, K.; Matyas, D. Adaptation and transformation. Clim. Chang. 2015, 133, $113-127$. [CrossRef]

91. Manuel-Navarrete, D.; Pelling, M. Subjectivity and the politics of transformation in response to development and environmental change. Global Environ. Chang. 2015, 35, 558-569. [CrossRef]

92. Andrachuk, M.; Armitage, D. Understanding social-ecological change and transformation through community perceptions of system identity. Ecol. Soc. 2015, 20, 26. [CrossRef]

93. Marshall, N.A.; Park, S.E.; Adger, W.N.; Brown, K.; Howden, S.M. Transformational capacity and the influence of place and identity. Environ. Res. Lett. 2012, 7, 1-10. [CrossRef]

94. Khanian, M.; Marshall, N.; Zakerhaghighi, K.; Salimi, M.; Naghdi, A. Transforming agriculture to climate change in Famenin County, West Iran through a focus on environmental, economic and social factors. Weather Clim. Extremes 2018, 21, 52-64. [CrossRef]

95. Pagiola, S.; Arcenas, A.; Platais, G. Can Payments for Environmental Services Help Reduce Poverty? An Exploration of the Issues and the Evidence to Date from Latin America. World Dev. 2005, 33, 237-253. [CrossRef]

96. Salzman, J. The promise and perils of payments for ecosystem services. Int. J. Innov. Sustain. Dev. 2005, 1, 5-20. [CrossRef]

97. Bowles, S.; Polania-Reyes, S. Economic Incentives and Social Preferences: Substitutes or Complements? J. Econ. Lit. 2012, 50, 368-425. [CrossRef]

98. Neuteleers, S.; Engelen, B. Talking money: How market-based valuation can undermine environmental protection. Ecol. Econ. 2015, 117, 253-260. [CrossRef]

99. Frame, D.J. The problems of markets: Science, norms and the commodification of carbon. Geogr. J. 2011, 177, 138-148. [CrossRef]

100. Ninan, K.N. Conserving and Valuing Ecosystem Services and Biodiversity: Economic, Institutional and Social Challenges; Routledge: London, UK, 2012; ISBN 1-136-56911-1.

101. Kronenberg, J.; Hubacek, K. Could Payments for Ecosystem Services Create an "Ecosystem Service Curse"? Ecol. Soc. 2013, 18, 10. [CrossRef]

102. Landell-Mills, N.; Porras, I.T. Silver Bullet or Fools' Gold?: A Global Review of Markets for Forest Environmental Services and Their Impact on the Poor; Instruments for sustainable private sector forestry series; International Institute for Environment and Development: London, UK, 2002; pp. 236-250.

103. Unruh, J.D. Carbon sequestration in Africa: The land tenure problem. Glob. Environ. Chang. 2008, 18, 700-707. [CrossRef]

104. Pollini, J. Carbon Sequestration for Linking Conservation and Rural Development in Madagascar: The Case of the Vohidrazana-Mantadia Corridor Restoration and Conservation Carbon Project. J. Sustain. For. 2009, 28, 322-342. [CrossRef]

105. Scales, I.R. Conservation and Environmental Management in Madagascar; Routledge: London, UK, 2014; ISBN 1-136-30908-X.

106. Cumming, G.S.; Olsson, P.; Chapin, F.S.; Holling, C.S. Resilience, experimentation, and scale mismatches in social-ecological landscapes. Landsc. Ecol. 2013, 28, 1139-1150. [CrossRef] 
107. Jagers, S.C.; Harring, N.; Löfgren, Å; Sjöstedt, M.; Alpizar, F.; Brülde, B.; Langlet, D.; Nilsson, A.; Almroth, B.C.; Dupont, S.; et al. On the preconditions for large-scale collective action. Ambio 2020, 49, 1282-1296. [CrossRef]

108. Kern, F.; Rogge, K.S. The pace of governed energy transitions: Agency, international dynamics and the global Paris agreement accelerating decarbonisation processes? Energy Res. Soc. Sci. 2016, 22, 13-17. [CrossRef]

109. Kronsell, A.; Khan, J.; Hildingsson, R. Actor relations in climate policymaking: Governing decarbonisation in a corporatist green state. Environ. Policy Gov. 2019, 29, 399-408. [CrossRef]

110. Cumming, G.S.; Cumming, D.H.M.; Redman, C.L. Scale mismatches in social-ecological systems: Causes, consequences, and solutions. Ecol. Soc. 2006, 11, 14-34. [CrossRef]

111. Mathevet, R.; Mauchamp, A. Evidence-based conservation: Dealing with social issues. Trends Ecol. Evol. 2005, 20, 422-423. [CrossRef] [PubMed]

112. Termeer, C.J.; Dewulf, A.; Van Lieshout, M. Disentangling scale approaches in governance research: Comparing monocentric, multilevel, and adaptive governance. Ecol. Soc. 2010, 15, 29-44. [CrossRef]

113. Bergsten, A.; Galafassi, D.; Bodin, O. The problem of spatial fit in social-ecological systems: Detecting mismatches between ecological connectivity and land management in an urban region. Ecol. Soc. 2014, 19, 6. [CrossRef]

114. Irawan, S.; Widiastomo, T.; Tacconi, L.; Watts, J.D.; Steni, B. Exploring the design of jurisdictional REDD+: The case of Central Kalimantan, Indonesia. For. Policy Econ. 2019, 108, 101853. [CrossRef]

115. Moeliono, M.; Gallemore, C.; Santoso, L.; Brockhaus, M.; Di Gregorio, M. Information networks and power: Confronting the "wicked problem" of REDD plus in Indonesia. Ecol. Soc. 2014, 19, 9. [CrossRef]

116. Head, B.W. Wicked problems in public policy. Public Policy 2008, 3, 101-118.

117. Patterson, J.; Schulz, K.; Vervoort, J.; van der Hel, S.; Widerberg, O.; Adler, C.; Hurlbert, M.; Anderton, K.; Sethi, M.; Barau, A. Exploring the governance and politics of transformations towards sustainability. Environ. Innov. Soc. Transit. 2017, 24, 1-16. [CrossRef]

118. Plummer, R. Social-ecological resilience and environmental education: Synopsis, application, implications. Environ. Educ. Res. 2010, 16, 493-509. [CrossRef]

119. Westley, F.; McGowan, K. The Evolution of Social Innovation: Building Resilience through Transitions; Edward Elgar Publishing: Cheltenham, UK, 2017; ISBN 1-78643-115-7.

120. Geels, F.W. Regime resistance against low-carbon transitions: Introducing politics and power into the multi-level perspective. Theory Cult. Soc. 2014, 31, 21-40. [CrossRef]

121. Lockwood, M.; Mitchell, C.; Hoggett, R. Unpacking 'regime resistance'in low-carbon transitions: The case of the British Capacity Market. Energy Res. Soc. Sci. 2019, 58, 101278. [CrossRef]

122. Haukkala, T. Does the sun shine in the High North? Vested interests as a barrier to solar energy deployment in Finland. Energy Res. Soc. Sci. 2015, 6, 50-58. [CrossRef]

123. Parlee, B.L.; Geertsema, K.; Willier, A. Social-ecological thresholds in a changing boreal landscape: Insights from Cree knowledge of the Lesser Slave Lake region of Alberta, Canada. Ecol. Soc. 2012, 17. [CrossRef]

124. Blythe, J.; Silver, J.; Evans, L.; Armitage, D.; Bennett, N.J.; Moore, M.-L.; Morrison, T.H.; Brown, K. The dark side of transformation: Latent risks in contemporary sustainability discourse. Antipode 2018, 50, 1206-1223. [CrossRef]

125. Bennett, N.J.; Dearden, P. Why local people do not support conservation: Community perceptions of marine protected area livelihood impacts, governance and management in Thailand. Mar. Policy 2014, 44, 107-116. [CrossRef]

126. Lam, D.P.; Hinz, E.; Lang, D.; Tengö, M.; Wehrden, H.; Martín-López, B. Indigenous and local knowledge in sustainability transformations research: A literature review. Ecol. Soc. 2020, 25, 3-28. [CrossRef]

127. Crane, T.A. Of models and meanings: Cultural resilience in social-ecological. Ecol. Soc. 2010, 15, 4-20. [CrossRef]

128. Sheppard, E.; Porter, P.W.; Faust, D.R.; Nagar, R. A World of Difference: Encountering and Contesting Development; Guilford Press: New York, NY, USA, 2009; ISBN 1-60918-123-9.

129. Biggs, R.; Westley, F.R.; Carpenter, S.R. Navigating the back loop: Fostering social innovation and transformation in ecosystem management. Ecol. Soc. 2010, 15, 9-34. [CrossRef]

130. DeFries, R.; Nagendra, H. Ecosystem management as a wicked problem. Science 2017, 356, $265-270$. [CrossRef] [PubMed]

131. Roberts, N. Wicked problems and network approaches to resolution. Int. Public Manag. Rev. 2000, 1, 1-19. 
132. Cashore, B.; Bernstein, S.; Humphreys, D.; Visseren-Hamakers, I.; Rietig, K. Designing stakeholder learning dialogues for effective global governance. Policy Soc. 2019, 38, 118-147. [CrossRef]

133. Frerks, G.E.; Dietz, T.; Zaag, P. van der Conflict and cooperation on natural resources: Justifying the CoCooN programme. In Conflict over Natural resources in the Global South. Conceptual Approaches; Bavinck, M., Pellegrini, L., Mostert, E., Eds.; CRC Press, Taylor \& Francis Group: London, UK, 2014; pp. $13-43$. ISBN 978-1-138-02040-5.

134. Tufa, F.A.; Amsalu, A.; Zoomers, E.B. Failed promises: Governance regimes and conflict transformation related to Jatropha cultivation in Ethiopia. Ecol. Soc. 2018, 23, 26. [CrossRef]

135. Krasny, M.E.; Lundholm, C.; Plummer, R. Resilience in Social-Ecological Systems: The Role of Learning and Education; Routledge: London, UK, 2011. [CrossRef]

136. Timko, J.A.; Amsalu, A.; Acheampong, E.; Teferi, M.K. Local Perceptions about the Effects of Jatropha (Jatropha curcas) and Castor (Ricinus communis) Plantations on Households in Ghana and Ethiopia. Sustainability 2014, 6, 7224-7241. [CrossRef]

137. Elshout, P.M.; van Zelm, R.; van der Velde, M.; Steinmann, Z.; Huijbregts, M.A. Global relative species loss due to first-generation biofuel production for the transport sector. GCB Bioenergy 2019, 11, 763-772. [CrossRef]

138. Balint, P.J.; Stewart, R.E.; Desai, A.; Walters, L.C. Wicked Environmental Problems: Managing Uncertainty and Conflict; Island Press: London, UK, 2011; ISBN 1-59726-475-X.

139. Ostrom, E. A diagnostic approach for going beyond panaceas. Proc Natl Acad. Sci USA 2007, 104, 15181-15187. [CrossRef]

140. Young, O.R.; Gasser, L. The Institutional Dimensions of Environmental Change: Fit, Interplay, and Scale; MIT press: Cambridge, MA, USA, 2002; ISBN 0-262-74024-9.

141. Roe, M. Governance, Policy and Juxtaposition; Springer: Cham, Switzerland, 2020.

142. Ansell, C.K.; Trondal, J.; Øgård, M. Governance in Turbulent Times; Oxford University Press: Oxford, UK, 2017; ISBN 0-19-873951-6.

143. Akamani, K.; Holzmueller, E.J.; Groninger, J.W. Managing wicked environmental problems as complex social-ecological systems: The promise of adaptive governance. In Landscape Dynamics, Soils and Hydrological Processes in Varied Climates; Springer: Cham, Switzerland, 2016; pp. 741-762.

144. Bruggemann, J.H.; Rodier, M.; Guillaume, M.M.; Andréfouët, S.; Arfi, R.; Cinner, J.E.; Pichon, M.; Ramahatratra, F.; Rasoamanendrika, F.; Zinke, J. Wicked social-ecological problems forcing unprecedented change on the latitudinal margins of coral reefs: The case of southwest Madagascar. Ecol. Soc. 2012, 17. [CrossRef]

145. Stahl, C.H.; Cimorelli, A.J. Environmental Public Policy Making Exposed; Springer: Cham, Switzerland, 2020.

146. Béné, C.; Evans, L.; Mills, D.; Ovie, S.; Raji, A.; Tafida, A.; Kodio, A.; Sinaba, F.; Morand, P.; Lemoalle, J. Testing resilience thinking in a poverty context: Experience from the Niger River basin. Glob. Environ. Chang. 2011, 21, 1173-1184. [CrossRef]

147. Ostrom, E. Sustainable social-ecological systems: An impossibility? SSRN Electron. J. 2007. [CrossRef]

148. Kates, R.W.; Travis, W.R.; Wilbanks, T.J. Transformational adaptation when incremental adaptations to climate change are insufficient. Proc. Natl. Acad. Sci. USA 2012, 109, 7156-7161. [CrossRef]

149. Bannink, D.; Trommel, W. Intelligent modes of imperfect governance. Policy Soc. 2019, 38, 198-217. [CrossRef]

150. Turnbull, N.; Hoppe, R. Problematizing 'wickedness': A critique of the wicked problems concept, from philosophy to practice. Policy Soc. 2019, 38, 315-337. [CrossRef]

151. Torfing, J.; Peters, B.G.; Pierre, J.; Sørensen, E. Interactive Governance: Advancing the Paradigm; Oxford University Press: Oxford, UK, 2012; ISBN 0-19-959675-1.

152. McKay, P.A. Living the Tame Life in Wicked Times-Environmental and Natural Resource Management in a Rapidly Changing World; Michigan State University: Michigan, MI, USA, 2013; ISBN 1-303-33183-7.

153. Noordegraaf, M.; Douglas, S.; Geuijen, K.; Van der Steen, M. Weaknesses of wickedness: A critical perspective on wickedness theory. Policy Soc. 2019, 38, 278-297. [CrossRef]

154. McKay, P.A.; Vogt, C.A.; Olabisi, L.S. Development and testing a diagnostic capacity tool for improving socio-ecological system governance. Environ. Syst. Decis. 2017, 37, 156-183. [CrossRef]

155. McKay, P.A.; Olabisi, L.S.; Vogt, C.A. Assessing improvements in socio-ecological system governance using mixed methods and the quality governance framework and its diagnostic capacity tool. Environ. Syst. Decis. 2020, 40, 41-66. [CrossRef] 
156. Termeer, C.J.; Dewulf, A.; Breeman, G.; Stiller, S.J. Governance capabilities for dealing wisely with wicked problems. Admin. Soc. 2015, 47, 680-710. [CrossRef]

157. Termeer, C.; Dewulf, A.; Karlsson-Vinkhuyzen, S.I.; Vink, M.; Van Vliet, M. Coping with the wicked problem of climate adaptation across scales: The Five R Governance Capabilities. Landsc. Urban Plan. 2016, 154, 11-19. [CrossRef] article distributed under the terms and conditions of the Creative Commons Attribution (CC BY) license (http://creativecommons.org/licenses/by/4.0/). 